\title{
Analysis of lactation curves, milk constituents, somatic cell count and urea in milk of cows by the mathematical model of Wood
}

\author{
Marcin Gołębiewski, Piotr Brzozowski, Łukasz Gołębiewski \\ Division of Cattle Breeding, Department of Animal Science, Warsaw University of Life Sciences, \\ Warszawa, Poland
}

Received January 13, 2010

Accepted September 21, 2010

\begin{abstract}
Analysis of lactation curves of milk, basic milk constituents, somatic cell count and urea in milk provide sufficient information for efficient dairy herd management and also is significant in genetic evaluation. The aim of the study was to apply the Wood's model to fit lactation curve of milk yield as well as fat, protein, dry matter, lactose, somatic cell count and urea in cows' milk. This study was conducted on dairy cows of Montbéliard $(n=686)$ and Polish Holstein-Friesian $(n=933)$ breeds. We analyzed data on the above mentioned milk constituents in the samples collected between 1995 and 2007. Data from 5,034 lactations were collected. Type C1 of the curve typical for standard lactation was the most frequent when daily milk yield, lactose and urea were analyzed. However, curves of fat protein and dry matter were described as type C4.

The Wood's model showed the highest accuracy when milk yield and protein content were investigated; poor fitting was observed for fat content. The Wood's model brought better accuracy for Polish Holstein-Friesian cows compared to Montbéliards. Precision of mathematical models fitting is $\mathrm{R}^{2}$ (adjusted determination coefficient). The highest values of $\mathrm{R}^{2}$ were noticed when lactation and protein curves were investigated. The lowest $\mathrm{R}^{2}$ was determined for urea and somatic cell count.
\end{abstract}

Montbéliard, Polish Holstein Friesian, linear regression, dairy cows

In genetic evaluation of dairy cattle, mathematical models of lactation are often used. The methods are referred to as test-day models (TDM). The main advantage of those methods is that the analysis is based on real data, not estimated or predicted on lactation yields (305 - day) and therefore less biased (Grzesiak et al. 2006). Another advantage of using TDM is the access to valuable information of lactation curves and persistency.

The success of every dairy enterprise strongly depends on decision made at various stages of the production cycle. Mathematical models describing changes in milk production within lactation (referred to as lactation curves) can be valuable and practical monitoring tools supporting herd management (Tekerli er al. 2000; Macciotta et al. 2005). Data from dairy record system and milk constituents curves as well as somatic cell count (SCC) and urea can be incorporated into mathematical models (Wood 1976; Stanton et al. 1992; Pollot 2004; Silvestre et al. 2009). Lactation curves provide sufficient information on incorrectness of feeding, metabolic diseases at the first stage of lactation and fertility (Jakobsen et al. 2002; Hansen et al. 2006; Swalve 2000). Cows with flatter lactation curves are more resistant to metabolic stress linked to energy deficit at the peak of the lactation and therefore less problematic (Solkner and Funchs 1987).

During lactation, milk productivity and fluctuations in its chemical composition are affected by genetic and environmental effects (Horan et al. 2005; Hansen et al. 2006). Many authors confirmed the influence of breed, parity and production system on the shape of lactation curves (Wood 1980).

First reference to a lactation curve model was attributed to Brody et al. (1924). After that many other mathematical models describing lactation curve were introduced (Kellog et al. 1977; Leon-Velarde et al. 1995; Rook et al. 2003). Nevertheless, the most often

Address for correspondence:

Marcin Gołębiewski

Division of Cattle Breeding, Department of Animal Science

Warsaw University of Life Sciences

Phone: (+48 22) 59-36533; fax: (+48 22) 59-36538

ul. Ciszewskiego 8, 02-786 Warszawa; Poland

http://www.vfu.cz/acta-vet/actavet.htm 
characterized are functions: gamma of Wood (Wood 1967, 1968, 1970, 1976), ALI (Ali and Schaeffer 1987), WIL (Wilmink 1987), GUO (Guo and Swalve 1995) and Legendre polynomials (Bohmanova et al. 2008). However, for modelling both convex (e.g. milk curve) and convey (e.g. fat and protein curves) functions, mostly with only one extreme, Wood's model was the best solution.

As the modeling ability of Wood's function referring to traits others than milk production hasn't been confirmed in scientific literature, the aim of the study was to investigate the ability of the model to fit lactation curves of milk yield (MY), fat (F\%), protein (P\%), dry matter (DM\%), lactose (L\%), somatic cell count (SCC) and urea (U) in cows' milk of two breeds as well as assessment of the quality and applicability of its combined outputs.

\section{Materials and Methods}

Data and farms

Our studies were conducted on dairy cows of Montbéliard (Mo) and Polish Holstein-Friesian (PHF) cows kept on six farms located in the southern part of Poland. The farms were characterized by different scale and production systems, i.e. 4 were of small scale and tied housing system, and 2 were of large scale and loose housing system.

All cows had their milk production recorded by the Polish Federation of Cattle Breeders and Dairy Farmers by method of AT 4 (cows were sampled once a month). Materials for further investigation consisted of data from milk reports involving information from milk samples of daily milk yield, fat, protein, lactose, dry matter, SCC and urea, collected between 1995 and 2007. Further analyses were carried out only on cows with 10 records per lactation. Over that period, data from 5034 lactations of 1619 cows (933 PHF and $686 \mathrm{Mo}$ ) were collected. Details of dairy performance of studied cows are presented in Table 1.

Table 1 . Average daily milk performance of studied cows by breed

\begin{tabular}{lrr}
\hline Trait & Breed & \\
\hline Number of lactations & $\mathrm{PHF}^{1}$ & $\mathrm{MO}^{2}$ \\
Daily milk production $(\mathrm{kg})$ & 2901 & 2133 \\
Fat (\%) & 22.73 & 20.55 \\
Protein (\%) & 4.48 & 4.22 \\
Lactose (\%) & 3.41 & 3.51 \\
Dry matter (\%) & 4.83 & 4.88 \\
SCC (k/ml)) & 13.47 & 13.32 \\
Urea (mg/ml) & 642.14 & 454.94 \\
\hline
\end{tabular}

\section{Model fit}

The Wood's mathematical model was used to fit lactation curve as well as curves of others chemical components of milk (Wood 1976). The model represents gamma type curve, and can

be expressed by function: $\mathrm{Y}_{\mathrm{n}}=\mathrm{an}^{\mathrm{b}} \mathrm{e}^{\mathrm{cn}}$; where

$\mathrm{Y}_{\mathrm{n}}$ - is the average daily yield in the $\mathrm{n}^{\text {th }}$ week, a - parameter describing general production ability related to peak lactation, $\mathrm{b}$ - parameter related to the ascending part of the curve between calving and peak of lactation, c - parameter related to the descending part of the curve following lactation peak, $\mathrm{n}$ - week of the lactation. The peak of lactation occurs when $n=-b / c$ SCC - Somatic cell count

and can be calculated by formula: $\mathrm{Y}_{\mathrm{n}(\max )}=\mathrm{a}(\mathrm{b} / \mathrm{c})^{\mathrm{b}} \mathrm{e}^{-\mathrm{b}}$. Since a non-linear form of regression does not guarantee convergence, Wood's function was transformed to its $\operatorname{logarithm}$ form: $\ln Y_{n}=\ln (a)+b \ln (n)-c n$.

Scripts were written in Visual Basic using Solver in MS Excel and run in order to calculate parameters of Wood's model.

Table 2. Possible curve shapes of Wood's model.

\begin{tabular}{llll}
\hline & \multicolumn{2}{c}{$\begin{array}{c}\text { Parameters of Wood's } \\
\text { model }\end{array}$} & \\
\hline Curve shape & $\mathrm{b}$ & $\mathrm{c}$ & Curve description \\
C1 & $\mathrm{b}>0$ & $\mathrm{c}<0$ & standard lactation curve \\
$\mathrm{C} 2$ & $\mathrm{~b}>0$ & $\mathrm{c}>0$ & continuously ascending curve \\
C3 & $\mathrm{b}<0$ & $\mathrm{c}<0$ & continuously descending curve \\
$\mathrm{C} 4$ & $\mathrm{~b}<0$ & $\mathrm{c}>0$ & inverted to standard curve \\
\hline
\end{tabular}

It is stated that Wood's model can fit analyzed traits curves in four different shapes (Wood 1976; Macciotta et al. 2005), mainly depending on the value of parameters $b$ and $c$, as $a$ is always positive and influences average level of production (Table 2). Type $\mathrm{C} 1$ represents the shape of the typical curve of daily milk yield while $\mathrm{C} 2$ and $\mathrm{C} 3$ correspond to continuously increasing and decreasing curves, respectively. The 
type $\mathrm{C} 4$ refers to the shape of reversed standard curve, with a descending initial phase and ascending phase after reaching the minimum.

Goodness of fit was estimated by the adjusted determination coefficient $\left(\mathrm{R}^{2}\right)($ Olori et al. 1999; Macciotta et al. 2005). The curves of all analyzed traits were divided into four groups according to $R^{2}\left(R^{2} \geq 0.75\right.$ and all lactations) and breed (Mo and PHF). Further investigation was carried out on curves with $\mathrm{R}^{2} \geq 0.75$. Individual curves of MY, F\%, P\%, L\%, DM\%, SCC and U were classified in the most common combinations (Silvestre 2009).

The analysis of variation (ANOVA) of SPSS software package was used to evaluate breed effect on coefficients of linear regression: $\mathrm{a}, \mathrm{b}$ and $\mathrm{c}$ as well as $\mathrm{R}^{2}$.

\section{Results and Discussion}

Each described lactation curve as well as curves of milk constituents and SCC were represented by four different shapes of curve with various frequencies (Table 3). Type C1 of the curve typical for standard lactation curve was the most frequent when daily milk yield, $\mathrm{L} \%$ and $\mathrm{U}$ were analyzed. However, curves of $\mathrm{F} \%, \mathrm{P} \%$ and $\mathrm{DM} \%$ were described as type $\mathrm{C} 4$. Remaining two curve shapes appeared very rarely within the analyzed traits. Frequencies of the type $\mathrm{C} 1$ and $\mathrm{C} 4$ of SCC were similar. Comparable to reported in the study frequencies of the curves were confirmed by Rekik and Gara (2004). Marcciotta et al. (2005), during fitting MY to Wood's model, reported $80 \%$ and $17 \%$ frequencies of type $\mathrm{C} 1$ and $\mathrm{C} 4$ of lactation curves, respectively. The most often appearing standard lactation curve shape (C1) for MY as well as its inverted shape (C4) for $\mathrm{F} \%$ and $\mathrm{P} \%$ content were confirmed by other authors (Stanton et al. 1992; Pollot 2004).

Table 3. Relative distribution of lactation curve types

\begin{tabular}{lcrrrrrr}
\hline Lactation type & MY & F\% & P\% & \multicolumn{1}{c}{ L $\%$} & \multicolumn{1}{c}{ DM $\%$} & \multicolumn{1}{c}{ SCC } & U \\
\hline C1 & $76.59 \%$ & $21.12 \%$ & $22.11 \%$ & $58.55 \%$ & $17.05 \%$ & $38.48 \%$ & $66.34 \%$ \\
C2 & $0.6 \%$ & $6.86 \%$ & $12.23 \%$ & $2.23 \%$ & $7.47 \%$ & $7.97 \%$ & $6.36 \%$ \\
C3 & $15.63 \%$ & $3.15 \%$ & $0.00 \%$ & $9.26 \%$ & $2.04 \%$ & $3.95 \%$ & $4.26 \%$ \\
C4 & $7.72 \%$ & $68.87 \%$ & $65.66 \%$ & $29.96 \%$ & $73.44 \%$ & $49.60 \%$ & $23.04 \%$ \\
total & $100 \%$ & $100 \%$ & $100 \%$ & $100 \%$ & $100 \%$ & $100 \%$ & $100 \%$ \\
\hline
\end{tabular}

MY- milk yield, F\%-fat, P\%-protein , DM\%-dry matter, L\%-lactose, SCC-somatic cell count, U-urea

Table 4. Six most frequent combinations of MY, F\%, P\%, L\%, DM\%, SCC and U curves

\begin{tabular}{cccccccccc}
\hline Combinations & MY & F\% & P\% & L\% & DM\% & SCC & U & N & $\%$ in total \\
\hline 1 & C1 & C4 & C4 & C1 & C4 & C4 & C1 & 194 & 11.81 \\
2 & C1 & C4 & C4 & C1 & C4 & C1 & C1 & 66 & 4.02 \\
3 & $\mathrm{C} 1$ & C4 & C4 & C1 & C4 & C4 & C4 & 46 & 2.80 \\
4 & $\mathrm{C} 3$ & C4 & C4 & C1 & C4 & C4 & C1 & 39 & 2.37 \\
5 & $\mathrm{C} 1$ & C4 & C4 & C4 & C4 & C4 & C1 & 38 & 2.31 \\
6 & $\mathrm{C} 1$ & C4 & C4 & C4 & C4 & C1 & C1 & 36 & 2.19 \\
\hline
\end{tabular}

MY- milk yield, \%-fat, P\%-protein, DM\%-dry matter, L\%-lactose, SCC-somatic cell count, U-urea

From $16000\left(4^{7}\right)$ possible combination of curves only $58 \%$ of them showed the case. The six most frequent combinations consist of only $25 \%$ of all theoretically possible combinations (Table 4). Nevertheless, except for Silvestre et al. (2009), who combined five traits, nobody investigated all lactation curves at the same time. Other authors also analyzed shape $\mathrm{F} \%$ and $\mathrm{P} \%$ but separately for each trait (Pollot 2004). Since milk is a mixture of chemical compounds, vitamins and minerals, either suspended or dissolved in water, there are links between particular constituents of milk as well as SCC. Higher frequency of the particular combination confirmed existence of those correlations. Easily noticeable is the relation between quantity of milk and $\mathrm{P} \%, \mathrm{~F} \%$ and $\mathrm{DM} \%$ in milk as well 
Table 5. Correlations between average values of studied cows based on milk records

\begin{tabular}{|c|c|c|c|c|c|c|c|c|}
\hline \multirow{9}{*}{ 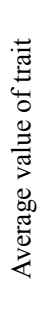 } & \multicolumn{8}{|c|}{ Average value of trait } \\
\hline & & MY & $\mathrm{F} \%$ & $\mathrm{P} \%$ & $\mathrm{~L} \%$ & DM\% & $\mathrm{SCC}$ & $\mathrm{U}$ \\
\hline & $\overline{M Y^{1}}$ & 1 & $-0.054 *$ & $-0.223 * *$ & -0.029 & $-0.148 * *$ & $-0.065 * *$ & $0.306 * *$ \\
\hline & $\mathrm{F} \%{ }^{2}$ & & 1 & $0.239 * *$ & $-0.093 * *$ & $0.865 * *$ & -0.004 & -0.020 \\
\hline & $\mathrm{P} \% 0^{3}$ & & & 1 & $0.054 *$ & $0.593 * *$ & $0.149 * *$ & $-0.147 * *$ \\
\hline & $\mathrm{L} \%{ }^{4}$ & & & & 1 & $0.217 * *$ & $-0.297 * *$ & $-0.054 *$ \\
\hline & $\mathrm{DM} \% \%^{5}$ & & & & & 1 & 0.004 & $-0.103 * *$ \\
\hline & $\mathrm{SCC}^{6}$ & & & & & & 1 & $-0.076 * *$ \\
\hline & $\mathrm{U}^{7}$ & & & & & & & 1 \\
\hline
\end{tabular}

Significance: $* * P \leq 0.01 ; * P \leq 0.05$;

MY- milk yield, F\%-fat, P\%-protein, DM\%-dry matter, L\%-lactose, SCC-somatic cell count, U-urea

Table 6. Correlations between parameters a of studied traits

\begin{tabular}{|c|c|c|c|c|c|c|c|c|}
\hline \multirow{9}{*}{ 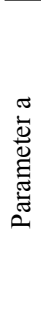 } & \multicolumn{8}{|c|}{ Parameter a } \\
\hline & & MY & $\mathrm{F} \%$ & $\mathrm{P} \%$ & $\mathrm{~L} \%$ & DM\% & $\mathrm{SCC}$ & $\mathrm{U}$ \\
\hline & $\overline{\mathrm{MY} 1}$ & 1 & $0.056^{*}$ & $-0.221 * *$ & $0.124 * *$ & -0.023 & $-0.078 * *$ & $0.154 * *$ \\
\hline & $\mathrm{F} \% 2$ & & 1 & 0.039 & $-0.280 * *$ & $0.896 * *$ & 0.040 & -0.092 \\
\hline & $\mathrm{P} \% 3$ & & & 1 & $-0.093 * *$ & $0.392 * *$ & $0.196 * *$ & $-0.066 * *$ \\
\hline & $\mathrm{L} \% 4$ & & & & 1 & $-0.127 * *$ & $-0.269 * *$ & $0.063 *$ \\
\hline & $\mathrm{DM} \% 5$ & & & & & 1 & 0.047 & $-0.119 * *$ \\
\hline & SCC6 & & & & & & 1 & $-0.058 *$ \\
\hline & U7 & & & & & & & 1 \\
\hline
\end{tabular}

Significance: ** at $P \leq 0.01 ; *$ at $P \leq 0.05$

MY-milk yield, F\%-fat, P\%-protein, DM\%-dry matter, L\%-lactose, SCC-somatic cell count, U-urea

Table 7. Relative frequencies of curves with $\mathrm{R}^{2}$ higher than 0.75 for analyzed traits

\begin{tabular}{lccc}
\hline Trait & Breed & & Percentage in all lactations \\
\hline & PHF & MO & \\
Number of lactation (n) & 933 & 686 & $36.75 \%$ \\
Milk curve & $63.88 \%$ & $62.39 \%$ & $11.92 \%$ \\
Fat curve & $15.33 \%$ & $7.43 \%$ & $43.42 \%$ \\
Protein curve & $47.37 \%$ & $38.05 \%$ & $17.48 \%$ \\
Lactose curve & $19.29 \%$ & $15.16 \%$ & $17.48 \%$ \\
Dry matter curve & $20.58 \%$ & $13.26 \%$ & $12.11 \%$ \\
SCC curve & $12.54 \%$ & $11.52 \%$ & $9.26 \%$ \\
Urea curve & $9.32 \%$ & $9.04 \%$ &
\end{tabular}

PHF-Polish Holstein-Friesian breed; MO- Montbéliard breed

as between L\% and U (Tsuruta et al. 2004). Supplementation but also confirmation of data indicating the existence of relation between particular milk constituents is presented in Table 5 which presents Pearson's correlations between average values of $\mathrm{MY}, \mathrm{F} \%, \mathrm{P} \%$, $\mathrm{L} \% \mathrm{DM} \%, \mathrm{SCC}$ and $\mathrm{U}$ in milk of studied cows based on real data originated from cows' records. Analysis confirmed existence of significant correlation between nearly all traits with only few exceptions (Table 5). We observed significant negative correlations between $\mathrm{MY}$ and $\mathrm{F} \%, \mathrm{P} \% \mathrm{DM} \%$ as well as SCC, and positive strong correlation between MY and $\mathrm{U}$. Urea content was negatively correlated with all investigated traits, excluding MY. Higher level of $\mathrm{L} \%$ causes significant but not rapid drop in $\mathrm{F} \%$. During investigation of correlation of parameter a (Table 6) in analyzed traits, we found that there is some disagreement between those results and those based on averages. In most cases strength, direction 
Table 8. Least square means and standard errors of determination covariants of analyzed traits

\begin{tabular}{|c|c|c|c|c|c|c|c|c|c|c|c|c|}
\hline \multirow{3}{*}{ Trait } & \multicolumn{4}{|c|}{ All lactations } & \multicolumn{8}{|c|}{ Lactations of $\mathrm{R}^{2} \geq 0.75$} \\
\hline & \multicolumn{2}{|c|}{ Breed } & \multicolumn{10}{|c|}{ Breed } \\
\hline & \multicolumn{2}{|c|}{ PHF } & \multicolumn{2}{|c|}{$\mathrm{MO}$} & & & \multicolumn{2}{|c|}{ PHF } & \multicolumn{2}{|c|}{$\mathrm{MO}$} & & \\
\hline \multirow{2}{*}{$\begin{array}{l}\text { Numbers of } \\
\text { lactation (n) }\end{array}$} & \multicolumn{2}{|c|}{933} & \multicolumn{2}{|c|}{686} & \multicolumn{2}{|c|}{ Total } & \multicolumn{2}{|c|}{596} & \multicolumn{2}{|c|}{428} & \multicolumn{2}{|c|}{ Total } \\
\hline & LSM & $\mathrm{Se}$ & LSM & $\mathrm{Se}$ & LSM & $\mathrm{Se}$ & LSM & $\mathrm{Se}$ & LSM & $\mathrm{Se}$ & LSM & $\mathrm{Se}$ \\
\hline Lactation curve & 0.75 & 0.07 & 0.74 & 0.08 & 0.74 & 0.01 & 0.87 & 0.00 & 0.88 & 0.00 & 0.87 & 0.00 \\
\hline Fat curve & 0.44 & 0.01 & 0.37 & 0.01 & 0.41 & 0.01 & $0.83 a$ & 0.01 & $0.81 \mathrm{a}$ & 0.01 & 0.82 & 0.01 \\
\hline Protein curve & 0.68 & 0.01 & 0.62 & 0.01 & 0.65 & 0.01 & $0.86 \mathrm{~A}$ & 0.00 & $0.84 \mathrm{~A}$ & 0.00 & 0.85 & 0.00 \\
\hline Lactose curve & 0.47 & 0.00 & 0.44 & 0.01 & 0.46 & 0.01 & 0.83 & 0.01 & 0.84 & 0.01 & 0.83 & 0.01 \\
\hline Dry matter curve & $0.50 \mathrm{~A}$ & 0.01 & $0.44 \mathrm{~A}$ & 0.01 & 0.47 & 0.01 & 0.83 & 0.00 & 0.83 & 0.01 & 0.83 & 0.00 \\
\hline SCC curve & 0.40 & 0.01 & 0.39 & 0.01 & 0.39 & 0.01 & 0.83 & 0.01 & 0.82 & 0.01 & 0.83 & 0.00 \\
\hline Urea curve & $0.37 \mathrm{~A}$ & 0.01 & $0.33 \mathrm{~A}$ & 0.09 & 0.35 & 0.01 & 0.82 & 0.01 & 0.84 & 0.01 & 0.83 & 0.01 \\
\hline
\end{tabular}

Significance: A- at $P \leq 0.01$; a - at $P \leq 0.05$

PHF-Polish Holstein-Friesian breed; MO- Montbéliard breed; LSM- Least square means; Se- Standard error

and significance were comparable to those obtained (Table 5). However, in some cases correlations were completely different either in strength, significance or even direction, e.g. correlation between $\mathrm{MY}$ and $\mathrm{F} \%$ and $\mathrm{L} \%$ or $\mathrm{DM} \%$ and $\mathrm{L} \%$.

Wood's model fit studied traits with various precision what was also observed by Wood (1976) and Silvestern et al. (2009). Unsettled accuracy of gamma model for fitting some of the analyzed traits can be illustrated as proportion of the curves with $\mathrm{R}^{2} \geq 0.75$ (Table 7 ). Wood's model showed the highest accuracy when MY and P\% were investigated. The fitting of $\mathrm{F} \%$ was quite poor as was also confirmed by Quinn et al. (2006). Comparing efficiency of the model for studied cows, it was stated that all curves of PHF were characterized by higher proportion of those with $\mathrm{R}^{2}>0.75$ than of $\mathrm{MO}$ ones. Great proportion of lactation curves with $\mathrm{R}^{2} \geq 0.75$ was also reported by Silvestern et al. (2009), Olori et al. (1999) and Marcciotta et al. (2005). However, even more accurate indicator of precision in explaining analyzed traits by the mathematical model is determination coefficient itself (Table 8). Since the Wood's model was originally designed for analyzing MY during lactation, the highest value of $\mathrm{R}^{2}$ was noticed when lactation curves were investigated. The model explained MY of all analyzed cows in 74\%. Similar precision was reported during analysis of $\mathrm{P} \%\left(\mathrm{R}^{2}=0.65\right)$. The lowest $\mathrm{R}^{2}$ was observed during $\mathrm{U}$ and $\mathrm{SCC}$ investigation. The $\mathrm{R}^{2}$ for those both traits were 0.35 and 0.39 , respectively. Wood's model brought better accuracy for PHF cows compared to MO. Nevertheless, differences were not significant, with two exceptions when DM\% and U were analyzed. Average values of determination coefficient were significantly higher for $\mathrm{MY}$ and $\mathrm{P} \%$ and lower for $\mathrm{F} \%$ then those described by Brzozowski et al. (1989).

Differences between MO and PHF cows in Wood's model parameters of all studied traits of all analyzed lactations and those with $\mathrm{R}^{2} \geq 0.75$ were depicted in Table 9 . Basically, significantly better $(P \leq 0.01)$ parameter a of MY of PHF was confirmed when, either all lactations or just those that fit model better $\left(\mathrm{R}^{2} \geq 0.75\right)$, were investigated. Wood's model's purer fitting of MY of PHF was caused by higher peak during the first stage of lactation. There were no differences between studied breed when parameters $\mathrm{b}$ and $\mathrm{c}$ of model were analyzed. Higher value a of F\% in milk of PHF was noticed, but significant differences between both breeds were observed for all lactations. Similar phenomenon was noticed during analysis of $\mathrm{b}$ and $\mathrm{c}$ of $\mathrm{F} \%$. MO cows' $\mathrm{F} \%$ characterized lower negative value of $\mathrm{b}$ and lower but positive value of $\mathrm{c}$ (for all lactations differences were significant at $P \leq 0.01)$. Since PHF cows showed higher MY during peak of lactation, decrease in F\% was more rapid (parameter b) of those cows in the first stage of lactation. Significantly 
Table 9. Wood's model parameters of analyzed traits of two breeds for all lactations and those with $\mathrm{R}^{2} \geq 0.75$

\begin{tabular}{|c|c|c|c|c|c|c|c|c|}
\hline \multirow{3}{*}{ Cecha } & \multicolumn{4}{|c|}{$\mathrm{R}^{2} \geq 0.75$} & \multicolumn{4}{|c|}{ all lacations } \\
\hline & \multicolumn{2}{|c|}{ PHF } & \multicolumn{2}{|c|}{$\mathrm{MO}$} & \multicolumn{2}{|c|}{ PHF } & \multicolumn{2}{|c|}{$\mathrm{MO}$} \\
\hline & LSM & $\mathrm{Se}$ & LSM & $\mathrm{Se}$ & LSM & $\mathrm{Se}$ & LSM & $\mathrm{Se}$ \\
\hline $\begin{array}{l}\text { Number of lactaions } \\
\text { Parameters of MY }\end{array}$ & 596 & & 428 & & 933 & & 686 & \\
\hline $\mathrm{a}$ & $33.29 \mathrm{~A}$ & 0.33 & $29.53 \mathrm{~A}$ & 0.69 & $31.84 \mathrm{~A}$ & 0.26 & $28.44 \mathrm{~A}$ & 0.47 \\
\hline $\mathrm{b}$ & 0.28 & 0.02 & 0.32 & 0.03 & 0.24 & 0.01 & 0.24 & 0.02 \\
\hline $\mathrm{c}$ & -0.15 & 0.04 & -0.16 & 0.09 & -0.13 & 0.00 & -0.13 & 0.01 \\
\hline \multicolumn{9}{|l|}{ Parameters of $\mathrm{F} \%$} \\
\hline $\mathrm{a}$ & 4.92 & 0.10 & 4.42 & 0.28 & $4.59 \mathrm{~A}$ & 0.03 & $4.24 \mathrm{~A}$ & 0.05 \\
\hline $\mathrm{b}$ & -0.33 & 0.03 & -0.22 & 0.09 & $-0.19 \mathrm{~A}$ & 0.01 & $-0.12 \mathrm{~A}$ & 0.02 \\
\hline $\mathrm{c}$ & 0.08 & 0.01 & 0.06 & 0.02 & $0.04 \mathrm{~A}$ & 0.00 & $0.03 \mathrm{~A}$ & 0.00 \\
\hline \multicolumn{9}{|l|}{ Parameters of $\mathrm{P} \%$} \\
\hline $\mathrm{a}$ & $2.92 \mathrm{~A}$ & 0.01 & $3.14 \mathrm{~A}$ & 0.02 & $3.05 \mathrm{~A}$ & 0.01 & $3.24 \mathrm{~A}$ & 0.02 \\
\hline $\mathrm{b}$ & -0.07 & 0.01 & -0.10 & 0.02 & $-0.07 \mathrm{a}$ & 0.01 & $-0.09 a$ & 0.01 \\
\hline $\mathrm{c}$ & 0.05 & 0.00 & 0.05 & 0.00 & 0.04 & 0.00 & 0.04 & 0.00 \\
\hline \multicolumn{9}{|l|}{ Parameters of L\% } \\
\hline $\mathrm{a}$ & $4.92 \mathrm{~A}$ & 0.02 & $5.04 \mathrm{~A}$ & 0.03 & $4.90 \mathrm{~A}$ & 0.01 & $4.98 \mathrm{~A}$ & 0.01 \\
\hline $\mathrm{b}$ & 0.07 & 0.01 & 0.05 & 0.01 & 0.03 & 0.00 & 0.02 & 0.00 \\
\hline $\mathrm{c}$ & -0.02 & 0.00 & -0.02 & 0.00 & -0.01 & 0.00 & -0.01 & 0.00 \\
\hline \multicolumn{9}{|l|}{ Parameters of DM\% } \\
\hline $\mathrm{a}$ & 13.38 & 0.03 & 13.26 & 0.06 & 13.38 & 0.03 & 13.26 & 0.06 \\
\hline $\mathrm{b}$ & $-0.08 \mathrm{a}$ & 0.00 & $-0.06 \mathrm{a}$ & 0.01 & $-0.07 \mathrm{a}$ & 0.00 & $-0.06 \mathrm{a}$ & 0.01 \\
\hline c & 0.02 & 0.00 & 0.02 & 0.00 & $0.023 \mathrm{~A}$ & 0.00 & $0.018 \mathrm{~A}$ & 0.00 \\
\hline \multicolumn{9}{|l|}{ Parameters of SCC } \\
\hline $\mathrm{a}$ & 577.89 & 175.83 & 570.42 & 246.49 & 471.04 & 33.96 & 335.09 & 60.74 \\
\hline $\mathrm{b}$ & -0.74 & 0.24 & -0.76 & 0.33 & -0.05 & 0.06 & -0.18 & 0.11 \\
\hline $\mathrm{c}$ & 0.28 & 0.05 & 0.32 & 0.07 & 0.06 & 0.01 & 0.09 & 0.03 \\
\hline \multicolumn{9}{|l|}{ Parameters of $U$} \\
\hline $\mathrm{a}$ & 222.85 & 3.42 & 267.75 & 6.02 & 220.77 & 3.40 & 228.52 & 6.08 \\
\hline $\mathrm{b}$ & 1.21 & 0.10 & 1.28 & 0.18 & 0.39 & 0.02 & 0.41 & 0.04 \\
\hline $\mathrm{c}$ & -0.26 & 0.02 & -0.34 & 0.04 & -0.08 & 0.01 & -0.10 & 0.01 \\
\hline
\end{tabular}

Significance: A- at $P \leq 0.01$; a - at $P \leq 0.05$

PHF-Polish Holstein-Friesian breed; MO- Montbéliard breed

MY- milk yield, F\%-fat, P\%-protein , DM\%-dry matter, L\%-lactose, SCC-somatic cell count, U-urea

higher $(P \leq 0.01)$ parameter a of $\mathrm{P} \%$ of $\mathrm{MO}$ cows was stated when both breeds were compared. PHF cows were characterized by noticeably smaller drop of $\mathrm{P} \%$ during the peak of lactation (when $\mathrm{R}^{2} \geq 0.75$ ). Wood's model underestimated the decrease in $\mathrm{P} \%$ of both studied breeds. Milk of MO cows also characterized by higher L\% compared to PHF $(P \leq 0.01)$. L\% curves explained by Wood's model were slightly underestimated in the peak phase of lactation. However, there were no significant differences when parameters $\mathrm{b}$ and $\mathrm{c}$ of $\mathrm{L} \%$ were investigated. Probably, differences of $\mathrm{F} \%, \mathrm{P} \%$ and $\mathrm{L} \%$ in milk of studied cows (higher $\mathrm{P} \%$ of $\mathrm{MO}$ milk or $\mathrm{F} \%$ of $\mathrm{PHF}$ ) affected $\mathrm{DM} \%$ in milk of both breeds equally. Nevertheless, DM\% curve was characterized by the faster drop of DM\% during the descending phase of PHF cows (parameter b) as well as its better growth of the ascending phase (parameter c). There were no significant differences between both breeds during SCC analysis. MO cows showed lower SCC in their milk if compared to PHF. Since SCC is affected by many factors (mainly environmental), SCC curves are very 
unstable and difficult to predict by any mathematical model. Also there were no significant differences when $\mathrm{U}$ was investigated. However, the value of a was higher when MO milk was analyzed. Similar to the case of DM\% curve also U curve is not precisely explained by Wood's model.

In the interpretation of output data of mathematic models it is important to consider its properties as well as biological and physiological fundamentals. In some cases, 10 records are not enough to fully represent some lactations (Olori et al. 1999). On the other hand, diseases (mastitis, metabolic diseases), injuries, record errors may also be the factors causing problems in representation of real genetic abilities of some cows (Wiggans et al. 2004). The distance between first record and peak of lactation may also affect the mathematical analysis. Bias in estimation of particular lactation curves also depends upon environmental effects or even random variation of individual cows (Olori et al. 1999). It is also worth mentioning that a single mathematical model, even if effective for particular traits, shows various accuracies for others even within one breed, as confirmed in the present study. This suggests the need to incorporate different factors in the process of modification of the existing models or designing new ones in terms of better precision and applicability. Practically, that means that for each analyzed trait within a breed, a different mathematic model should be used.

\section{References}

Ali TE, Schaeffer LR 1987: Accounting for covariances among test day milk yields in dairy cows. Can J Dairy Sci 67: 637-644

Bohmanova J, Miglior F, Jamrozik J, Misztal I, Sullivan PG 2008: Comparison of random regression models with Legendre polynomials and linear splices for production traits and somatic score cells of Canadian Holstein cows. J Dairy Sci 91: 3627-3638

Brody S, Turner CW, Ragsdale AC 1924: The relation between the initial rise and subsequent decline of milk secretion following parturition. J Gen Physiol 6: 541-545

Brzozowski P, Jasiorowski H, Reklewski Z 1989: Krzywe laktacji mieszańców $F_{1} 9$ odmian bydła fryzyjskiego z krajowym bydłem czarno-białym. Rocz Nauk Rol 105: 7-18

Grzesiak W, Błaszczyk P, Lacroix R 2006: Methods of predicting milk yield in dairy cows - Predictive capabilities of Wood's lactation curve and artificial neural networks (ANNs). Comput Electron Agr 54: 69-83

Guo Z, Swalve HH 1995: Modeling of lactation curve as sub-model in the evaluation of test day records. Interbull Bulletin 11: 4-7

Hansen JV, Friggens NC, Hojsgaard S 2006: The influence of breed and parity on milk yield, and milk yield acceleration curves. 104: 53-62

Horan B, Dillon P, Berry DP, O'Connor P, Rath M 2005: The effect of strain of Holstein-Friesian, feeding system and parity on lactation curves characteristic of spring-calving dairy cows. Livest Prod 95: 231-241

Jakobsen J, Madsen P, Jensen J, Peersen J, Cristiensen LG, Sorensen DA 2002: Genetic parameters for milk production and persistency for Danish Holsteins estimated in random regression models using REML. J Dairy Sci 85: 1607-1616

Kellog DW, Urquhart NS, Ortega AJ 1977: Estimating Holstein lactation curve with a gamma curve. J Dairy Sci 60: $1308-1315$

Leon-Velarde CU, McMilan I, Gentry RD, Wilton W 1995: Models for estimating typical lactation curves in dairy cattle. J Anim Breed Genet 112: 333-340

Macciotta NPP, Vicario D, Cappio-Borlino A 2005: Detection of different shapes of lactation curve for milk yield in dairy cattle by empirical mathematical models. J Dairy Sci 88: 1178-1191

Olori VE, Brotherstone S, Hill WG, McGuric BJ 1999: Fit of standard models of the lactation curve to weekly records of milk production of cows in single herd. Livest Prod 58: 55-63

Pollot GE 2004: Deconstructing milk yield and composition during lactation using biologically based lactation models. J Dairy Sci 87: 2375-2387

Qiunn N, Killen L, Buckley F 2006: Modeling fat and protein concentration curves fore to weekly records of milk production of cows in single herd. Livest Prod 45: 13-23

Rekik B, Gara AB 2004: Factors affecting accuracy of atypical lactations for Holstein-Friesian cows. Livest Prod Sci 87: 245-250

Rook A, France J, Dhanoa M 1993: On the mathematical description of lactation curve. J Agric Sci Camb 121: $97-102$

Silvestre ADM, Martins AM, Santos MM, Ginja JA, Colaco JA 2009: Lactation curves for milk, fat and protein in dairy cows: A full approach. Livest Sci 122: 308-313 
Solkner J, Funchs W 1987: A comparison of different measures of persistency with special respect to variation of test day yields. Livest Prod Sci 16: 305-319

Stanton SL, Jones IR, Everett RW, Kachman SD 1992: Estimating milk, fat and protein lactation curves with a test day model. J Dairy Sci 75: 1691-1700

Swalve HH 2000: Theoretical basis and computational methods for different test-day genetic evaluation methods. J Dairy Sci 83: 1115-1124

Tekerli M, Akici Z, Dogan I, Acan A 2000: Factors affecting the shape of lactation curves of Holstein cows from the Balikesir province of Turkey. J Dairy Sci 83: 1381-1386

Tsuruta S, Misztal I, Lawlor TJ 2004: Genetic correlation among production, body size, udder and productive life traits over time in Holsteins. J Dairy Sci 87: 1457-1468

Wilmink JBM 1987: Comparison of different methods of predicting 305-day milk yield using means calculated from within-herd lactation curves. Livest Prod Sci: 17 1-17

Wiggans GR, VanRaden PM, Philpot JC 2004: Technical note: detection and adjustments of abnormal test-day yields. J Dairy Sci 86: 2721-2724

Wood PDP 1967: Algebraic model of the lactation curve in cattle. Nature 216: 164-165

Wood PDP 1968: Factors affecting persistency of lactation in cattle. Nature 218: 894

Wood PDP 1970: A note on repeatability of parameters of the lactation curve in cattle. Anim Prod 12: 535-538

Wood PDP 1976: Algebraic models of lactation curves for milk, fat and protein production, with estimates of seasonal variation. Anim Prod 22: 35-40

Wood PDP 1980: Breed variation in the shape of the lactation curve of cattle and their implication for efficiency. Anim Prod 31: 131-141 